\title{
RAZGRANIČENJE INSTITUTA DOPRINOSA OŠTEĆENIKA VLASTITOJ ŠTETI I PODIJELJENE ODGOVORNOSTI ZA ŠTETU
}

DOI: $10.3935 /$ zpfz.69.56.10

Izvorni znanstveni rad

Primljeno: rujan 2019.

U radu se analiziraju dva instituta koja utječu na odgovornost štetnika za nastalu štetu - doprinos oštećenika vlastitoj šteti i institut podijeljene odgovornosti. S obzirom na vrlo česte dvojbe u sudskoj praksi, a ponekad i u pravnoj znanosti, o upotrebi navedenih instituta, kako glede njihova nazivlja tako i glede pretpostavki cije ostvarenje je пužno za njihovu primjenu, u radu se nastoji upozoriti na međusobne razlike s ciljem pravilnije i lakše primjene. Konačno je naglasak na prepoznavanju pretpostavki instituta doprinosa oštećenika prema važećem uređenju u Zakonu o obveznim odnosima. Osim prikaza stavova u pravnoj literaturi, posebno se analiziraju pojedine sudske odluke radi boljeg uvida u neujednačenost sudske prakse u primjeni navedenih instituta radi njihova lakšeg razlikovanja te posljedično $i$ odgovarajuće primjene.

Ključne riječi: doprinos oštećenika, podijeljena odgovornost, pristanak oštećenika, naknada štete, posredni oštećenici

\section{UVOD}

Odgovornost za štetu tema je čija aktualnost ni danas ne jenjava, što pokazuje broj predmeta naknade štete koji se zaprimaju na sudovima u Republici

Dijana Vragović, mag. iur., viša sudska savjetnica na Županijskom sudu u Zagrebu privremeno raspoređena u rad na Vrhovni sud Republike Hrvatske, Trpimirova 25, Zagreb,dijanahrstic@yahoo.com,

ORCID ID: orcid.org/0000-0002-3025-0698 
Hrvatskoj. ${ }^{1}$ S obzirom na širok raspon odredbi Zakona o obveznim odnosima kojima je regulirana odgovornost za štetu, kao i s obzirom na odredbe drugih zakona koji uređuju institut odgovornosti za štetu izvan općih propisa, razvidno je da se pitanje odgovornosti za štetu vrlo često javlja kao predmet ispitivanja ne samo u okviru sudske prakse nego i pravne znanosti. ${ }^{2}$ Kako bi se mogla donijeti odluka o osnovanosti zahtjeva za naknadu štete, potrebno je utvrditi jesu li ispunjene pretpostavke takve odgovornosti, a često odgovoriti i na pitanje kada nastaju okolnosti koje dovode do njezina umanjenja ili isključenja. S tim u vezi u nastavku rada analizirat će se dva instituta - doprinos oštećenika nastanku štete i podijeljena odgovornost za štetu, s naglaskom na razlike koje između njih postoje. ${ }^{3}$ Ujedno će se prikazati koje dvojbe postoje oko primjene

1 U 2018. godini na prvostupanjskim općinskim sudovima u Republici Hrvatskoj zaprimljeno je 9312 predmeta koji nose oznaku "naknada štete", na drugostupanjskim županijskim sudovima zaprimljena su ukupno 5173 predmeta, na prvostupanjskim trgovačkim sudovima ukupno 1729 predmeta, na Visokom trgovačkom sudu ukupno 207 predmeta, a na Vrhovnom sudu Republike Hrvatske u povodu izjavljene revizije 298 predmeta - službeni podaci pribavljeni od Ministarstva pravosuđa RH, Službe za statističko praćenje i analitiku.

2 Primjerice, Zakon o obveznim osiguranjima u prometu, Zakon o radu, Zakon o zaštiti na radu, Zakon o odgovornosti za štetu nastalu uslijed terorističkih akata i javnih demonstracija, Zakon o odgovornosti Republike Hrvatske za štetu uzrokovanu od pripadnika hrvatskih oružanih i redarstvenih snaga tijekom Domovinskog rata, Zakon o medijima, Zakon o trgovačkim društvima, Zakon o sudovima, Pomorski zakonik itd.

3 U hrvatskoj pravnoj znanosti uobičajeno je da se kao pretpostavke odgovornosti za štetu navode: štetnik, oštećenik, štetna radnja, šteta, uzročna veza, protupravnost i krivnja. U onim slučajevima u kojima zakon predviđa objektivnu odgovornost za štetu krivnja ne predstavlja jednu od pretpostavki odgovornosti. S obzirom na činjenicu da naš Zakon o obveznim odnosima iz 2005. godine u čl. 1045. izričito ne navodi protupravnost kao jednu od pretpostavki odgovornosti za štetu, postavilo se pitanje je li protupravnost uistinu jedna od nužnih pretpostavki. Tim više što je u nekim slučajevima zakonom propisano da će osoba koja postupa u skladu sa zakonom, odnosno poduzima radnju na koju je zakonom izričito ovlaštena, ipak odgovarati za štetu koja pritom nastane (npr. pravo vlasnika životinje da pristupi na tuđe zemljište na koje je životinja dospjela uz obvezu naknade štete koja pritom nastane vlasniku ili odgovornost za štetu osobe od koje je otklonjena šteta i to za štetu koju je pretrpio onaj koji je od nje otklonio opasnost štete), makar šteta nije nastala protupravnom već dopuštenom radnjom. U ovom se radu samo upozorava na dileme koje postoje o protupravnosti kao pretpostavki odgovornosti za štetu jer bi opširnije izlaganje prešlo granice teme ovog rada. Detaljnije o navedenom pogledati u: Stipković, Z., Protupravnost kao pretpostavka odgovornosti za štetu, Pravni fakultet, Zavod za građanskopravne znanosti i porodično pravo, Zagreb, 1991. i Klarić, P., Odštetno pravo, Narodne novine, Zagreb, 1995. 
instituta doprinosa oštećenika i pristanka oštećenika na štetu s obzirom na to da oba instituta utječu na odgovornost štetnika te dovode do njezina isključenja odnosno umanjenja.

Doprinos oštećenika vlastitoj šteti je institut definiran odredbom čl. 1092. st. l. i 2. Zakona o obveznim odnosima iz 2005. ${ }^{4}$, kojom je propisano da oštećenik koji je pridonio da šteta nastane ili da bude veća nego što bi inače bila ima pravo samo na razmjerno sniženu naknadu. U slučaju kada nije moguće utvrditi koji dio štete potječe od oštećenikove radnje ili propusta, sud će dosuditi naknadu vodeći računa o okolnostima slučaja. Smisao te odredbe jest umanjiti odgovornost štetnika za nastalu štetu svodeći njegovu obvezu na onaj opseg koji zaista odgovara šteti koja se može pripisati njegovoj štetnoj radnji. Drugim riječima, svrha ovog instituta jest onemogućavanje da se štetniku stavlja na teret ono što je posljedica tuđe radnje, odnosno radnje oštećenika. ${ }^{5}$

Prema navedenoj odredbi doprinos oštećenika može se javiti u dva oblika kao doprinos nastanku štete (u kojem slučaju bez djelovanja oštećenika šteta ne bi uopće nastala ili ne bi nastala konkretnom oštećeniku) - te kao doprinos povećanju štete (radnjom ili propustom poduzimanja radnji radi umanjenja već nastale štete). ${ }^{6}$ Iako se primjena citirane odredbe naizgled čini jednostavnom, drukčiji zaključak proizlazi iz pregleda aktualne (i starije) sudske prakse, kao i iz mišljenja pojedinih autora pravne znanosti. Nerijetko se u odlukama sudova prilikom primjene odredbe čl. 1092. ZOO/05 govori o podijeljenoj odgovornosti ili suodgovornosti oštećenika za nastalu štetu, a ne o njegovu doprinosu. Poistovjećivanje navedenih naziva nije opravdano, kako će se detaljnije i prikazati u nastavku rada. Pritom valja napomenuti da ovdje nije riječ samo o terminološkom razgraničenju pojmova, odnosno zakonskih naziva instituta radi njihove odgovarajuće primjene, već je ujedno riječ o teorijskom problemu kojim se zalazi u područje pretpostavaka odgovornosti za štetu.

4 Zakon o obveznim odnosima (Narodne novine, br. 35/2005, 41/2008, 78/2015 i 29/2018), dalje u tekstu: ZOO/05.

5 Ovdje valja napomenuti da se u radu upotrebljava izraz djelovanje odnosno ponašanje oštećenika na način da se njime obuhvaća ne samo radnja nego i propust oštećenika kada je on doveo do nastanka štete u smislu odredbe čl. 1092. st. 2. ZOO/05.

6 O problematici doprinosa oštećenika nastanku štete općenito, odnosno nastanku vlastite štete vidi opširnije u poglavlju 4. Pretpostavke doprinosa oštećenika prema odredbi čl. 1092. ZOO/05. 


\section{OSVRT NA AKTUALNU SUDSKU PRAKSU U PRIMJENI ODREDBE ČL. 1092. ZOO/05.}

Problem neodgovarajućeg korištenja termina kojima se sadržajno označava doprinos oštećenika šteti nije problem samo starije sudske prakse, jer je neusklađenost u njihovu korištenju i dalje vidljiva u aktualnoj sudskoj praksi na svim instancama sudovanja, unatoč izmjenama Zakona o obveznim odnosima.

U prilog tome valja upozoriti na praksu Vrhovnog suda Republike Hrvatske (dalje u tekstu: VSRH), koji je u jednoj odluci ocijenio da postoji podijeljena odgovornost za nastalu štetu i to u omjeru 50 \% na strani tužitelja kao oštećenika i 50 \% na strani tuženika štetnika te zaključio da postoji podijeljena odgovornost za nastalu štetu u navedenom omjeru u smislu odredbe čl. 1092. st. $1 . \mathrm{ZOO} / 05 .{ }^{7} \mathrm{U}$ drugoj odluci istog suda navedeni pojmovi upotrebljavaju se na način da se uopće ne radi razlika između navedenih instituta, već se oba termina koriste prilikom primjene navedene odredbe. ${ }^{8}$

7 Revr-174/14-2 od 28. svibnja 2014. “Obzirom na takva činjenična utvrđenja pravilno je sud drugoga stupnja ocijenio da postoji podijeljena odgovornost za nastalu štetu i to u omjeru 50 \% na strani tužitelja i 50 \% na strani tuženika. Upravo činjenica da je praksa kod tuženika bila da se zaštitne naočale ne koriste kod radne operacije kakvu je obavljao tužitelj i kojom prilikom je došlo do povrede, te činjenica da tuženik nije osigurao svojim radnicima zaštitne naočale odgovarajuće kvalitete, prema utvrđenju nižestupanjskih sudova, opravdava zaključak da postoji podijeljena odgovornost za nastalu štetu u gore navedenom omjeru u smislu odredbe čl. 1092. st. 1. Zakona o obveznim odnosima (Narodne novine, br. 35/2005, 41/2008, 125/2011, dalje ZOO)".

$8 \quad$ Rev-1555/09-3 od 5. studenog 2014. “U revizijskoj fazi postupka i nadalje je sporan omjer podijeljene odgovornosti odnosno primjena odredbe čl. 1092. st. 1. ZOO. Polazeći od činjeničnih utvrđenja u postupku koji je prethodio reviziji, te imajući na umu da su oba sudionika prometne nezgode postupila protivno naprijed citiranim odredbama ZOSPC, prema ocjeni ovoga suda pogrešno je drugostupanjski sud primijenio materijalno pravo (čl. 1092. ZOO), ocijenivši doprinos prednika prvotužitelja i drugotužiteljice J. Š. nastanku prometne nezgode 70 \%. Naime, iako je pravilno shvaćanje drugostupanjskog suda da je u okolnostima konkretnog slučaja J. Š. bio dužan, uključujući se u promet sa sporedne lokalne ceste, propustiti vozilo koje se kreće cestom s pravom prvenstva, jer da je to učinio do prometne nezgode ne bi došlo, ostale utvrđene činjenice po nižestupanjskim sudovima upućuju da je drugostupanjski sud "precijenio" doprinos sada pok. J. Š. nastanku prometne nezgode ocijenivši ga $70 \%$. Prema tome, imajući na umu da se osiguranik tuženika (osim što je bio pod utjecajem alkohola, kao i J. Š.) kretao u naseljem mjestu brzinom $111 \mathrm{~km} / \mathrm{h}$, što je prekoračenje za $51 \mathrm{~km} / \mathrm{h}$ (ograničenje je bilo $60 \mathrm{~km} / \mathrm{h}$ ) i to ne svojom desnom stranom nego lijevom stranom kolnika, kod utvrđenja da se vozio dopuštenom brzinom i desnom stranom kolnika da do prometne nesreće uopće ne 
S druge strane, u pojedinim odlukama VSRH-a navedeni se termini jasno razgraničuju, pa je u odluci Rev-903/10-2 od 3. studenog 2010. izričito rečeno: "U odnosu na odredbu čl. 192. ZOO/91 citirana odredba je promijenjena u nazivu samog članka, jer umjesto "podijeljena odgovornost" novi je naziv "doprinos oštećenika vlastitoj šteti", a novi propis je nadopunjen u tom pravcu da oštećenik može pridonijeti vlastitoj šteti ne samo radnjom već i propustom. Slijedom izloženog proizlazi da smisao ranijih propisa nije izmijenjen Zakonom o obveznim odnosima iz 2005."

Neujednačenost sudske prakse u pogledu primjene navedenog instituta nije boljka samo na najvišoj instanci sudovanja, već se javlja i u odlukama prvostupanjskih i drugostupanjskih sudova. ${ }^{9}$ Unatoč tome što je doprinos oštećenika sada izričito uređen odredbom čl. 1092. ZOO/05 iz koje ne bi proizlazilo da je krivnja oštećenika nužna pretpostavka doprinosa nastanku štete, i dalje se u sudskoj praksi pojavljuje nesuglasje oko pretpostavki primjene navedene odredbe. Tako je u presudi Županijskog suda u Zagrebu broj Gž-7410/15-6 od 28. studenog 2017. iznesen zaključak da se "po prigovoru štetnika o podijeljenoj odgovornosti u parnici trebaju raspraviti sva činjenična pitanja koja su relevantna za ocjenu da li je i sam oštećenik nekom svojom radnjom ili propustom pridonio nastanku štetnog događaja i štetnih posljedica, dakle svojom krivnjom u građansko pravnom smislu."

U presudi Gžn-430/13-2 od 28. siječnja 2014. isti sud zaključuje da se ... "prema odredbi čl. 192. ZOO o podijeljenoj odgovornosti mora raditi o događaju u kojem je oštećeni sudjelovao u svojoj vlastitoj šteti, odnosno mora postojati uzročna veza između radnje oštećenog i određenog dijela vlastite štete kao posljedice zajedničkog djelovanja. Stoga, iz utvrđenog činjeničnog stanja po ocjeni ovog drugostupanjskog suda, za nastalu štetu isključivo je odgovoran tuženik, te je u obvezi naknaditi štetu tužitelju sukladno odredbi čl. 154. st. 1. Zakona o obveznim odnosima (Narodne novine, br. 53/1991, 73/1991, 3/1994, 7/1996 i 112/1999 - dalje: ZOO), dok za utvrđenje tužiteljeve krivnje nema temelja."

Upravo prikazane dvojbe u primjeni instituta doprinosa oštećenika vlastitoj šteti i podijeljene odgovornosti u pravnoj literaturi i praksi te nekonzistentnost u korištenju navedenih termina upućuju na potrebu aktualiziranja ove teme te jasnije i detaljnije obrade spomenutih instituta.

bi došlo, i prema ocjeni ovoga suda pravilan je zaključak prvostupanjskog suda da je doprinos J. Š. nastanku prometne nezgode $20 \%$."

9 Tako primjerice u odlukama Županijskog suda u Zagrebu, Gž-7104/15-4 od 9. siječnja 2019., Gžn-2516/14-2 od 7. veljače 2017. i Gžn-2371/14-2 od 8. travnja 2015. 


\section{DOPRINOS OŠTEĆENIKA VLASTITOJ ŠTETI - ANALIZA INSTITUTA}

Razlog zbog kojeg se često upotrebljava termin podijeljene odgovornosti kada se primjenjuju odredbe o doprinosu oštećenika treba potražiti u prijašnjim odredbama Zakona o obveznim odnosima iz 1978. ${ }^{10}$, ali i u pravnim pravilima Općeg građanskog zakonika. ${ }^{11}$

Tako je u ZOO/78 odredbom čl. 192. doprinos oštećenika bio uređen pod nazivom podijeljena odgovornost, makar odredba u stavku l. sadržajno odgovara odredbi današnjeg čl. 1092. st. 1. ZOO/05. Pojedini autori upozoravali su na neadekvatnost naziva citirane odredbe ističući potrebu razgraničenja navedenih instituta. ${ }^{12}$ Naime, podijeljena odgovornost pretpostavlja odgovornost više osoba za istu štetu, u kojem slučaju svaka od njih, u pravilu, odgovara za dio štete koji je prouzročila. ${ }^{13}$ Međutim, ako doprinos oštećenika promatramo kao podjelu odgovornosti između štetnika i oštećenog, onda nužno proizlazi zaključak da osim štetnika i oštećenik odgovara za vlastitu štetu. Prema mišljenju nekih autora u tom slučaju doprinos oštećenika dovodi do suodgovornosti štetnika i oštećenog, što posljedično dovodi do umanjenja naknade štete jer je u tom slučaju i oštećenik dijelom štetnik. ${ }^{14}$ Slično tumači i Vuković, navodeći da se oštećenikov doprinos ne sastoji u povredi dužnosti staranja jer se navedena

10 Zakon o obveznim odnosima (Službeni list SFRJ, br. 29/1978, 39/1985, 46/1985, 57/1989; Narodne novine, br. 3/1991, 73/1991, 111/1993, 3/1994, 107/1995, 7/1996, 112/1999 i 88/2001), dalje u tekstu: ZOO/78.

11 Justizgesetzsammlung 1/1811; dalje u tekstu: OGZ, bio je u primjeni na području Republike Hrvatske od 1. svibnja 1853. do donošenja Zakona o nevažnosti pravnih propisa donesenih prije 6 . travnja 1941. godine i za vrijeme neprijateljske okupacije (Službeni list FNRJ, br. 86/1946 i 105/1947), nakon čega se njegove odredbe primjenjuju kao pravna pravila s ograničenom primjenom na odnose koji nisu uređeni postojećim propisima i to samo ako nisu u suprotnosti s Ustavom FNRJ, ustavima narodnih republika, zakonima i ostalim postojećim propisima donesenim od nadležnih organa nove države, kao i s načelima ustavnog poretka Federativne Narodne Republike Jugoslavije i njenih republika (čl. 4. st. 1.). I nakon stupanja na snagu ZOO/78 postojala je potreba za primjenom pojedinih pravnih pravila OGZ-a radi popunjavanja postojećih pravnih praznina u području obveznog prava, primjerice kod ugovora o darovanju, sve do donošenja ZOO/05.

12 Crnić, J., Odgovornost više osoba za istu štetu i podijeljena odgovornost, Naša zakonitost, br. 9-70, 1987., str. 1047.

13 Postoje iznimke od navedene podjele odgovornosti kad je zakonom propisana solidarna odgovornost više osoba koje su štetu prouzročile (npr. čl. 1107. ZOO/05).

14 Klarić, P.; Vedriš, M., Građansko pravo, Narodne novine, 2008., Zagreb, str. 626. 
dužnost prema sebi ne može povrijediti, već da se takvom radnjom ili propustom oštećenika zapravo nanosi šteta štetniku, zbog čega je opravdano utvrđivati krivnju oštećenog. ${ }^{15}$

Za razliku od iznesenog stava, drugi autori smatraju da između štetnika i oštećenog ne može doći do podjele odgovornosti za nastalu štetu jer oštećenik ne odgovara sam sebi za štetu koju je prouzročio. ${ }^{16}$ Posljedica njegova djelovanja koja je dovela do nastanka ili povećanja štete očituje se kao element za umanjenje odgovornosti štetnika jer nitko ne može zahtijevati od druge osobe da mu nadoknadi štetu u dijelu u kojem ju je sam uzrokovao. U prilog navedenom tumačenju govori i izmjena navedene odredbe u ZOO/05, koji napušta naziv podijeljene odgovornosti kada uređuje doprinos oštećenika nastanku štete, zadržavajući gotovo jednako sadržajno uređenje. Osim toga, valja naglasiti da je institut doprinosa oštećenika smješten u dijelu ZOO/05, čije poglavlje nosi naslov Obujam i visina imovinske štete, a ne u dijelu koji uređuje suodgovornost ili podijeljenu odgovornost više osoba za štetu. ${ }^{17}$

Inzistiranje na preciznom korištenju navedenih termina prilikom primjene odredbe čl. 1092. ZOO/05 važno je zato što se različite pretpostavke trebaju ostvariti za primjenu instituta doprinosa oštećenika nastaloj šteti od pretpostavki nužnih za postojanje podijeljene odgovornosti dvaju štetnika. Kako bismo mogli odgovoriti na pitanje koje su to pretpostavke doprinosa oštećenika nastaloj šteti u smislu sada važeće odredbe čl. 1092. ZOO-a, potrebno je analizirati navedenu odredbu i njezino tumačenje sagledati i kroz razvoj pravne znanosti.

Prije donošenja Zakona o obveznim odnosima 1978. godine doprinos oštećenika bio je uređen paragrafom 1304. OGZ-a kojim je bilo propisano "Ako je u kakvoj šteti kriv također oštećenik, tad nosi i on štetu razmjerno s oštetiocem, a ako se razmjerje odrediti ne može, nose štetu na jednake dijelove." Doslovnim tumačenjem odredbe proizlazilo bi da je za doprinos oštećenika nastanku štete bilo potrebno njegovo skrivljeno ponašanje. Praksa je u skladu s navedenim tumačenjem i utvrđivala krivnju štetnika i oštećenog te ih prebijala na osnovi čega se utvrđivala preostala odgovornost štetnika za štetu. ${ }^{18}$ Prebijanje se provodilo tako da se dijelila krivnja između oštećenika i štetnika prema stupnju

15 Vuković, M., Obvezno pravo, knjiga I., Uvod, odgovornost za štetu i ostale vanugovorne obveze, Školska knjiga, Zagreb, 1956., str. 284.

16 Grbin, I., Popravljanje imovinske štete, 1. dio, Informator, br. 5441-5442, 2006., Zagreb, i Popravljanje imovinske štete, 2. dio, Informator, br. 5443, 2006., Zagreb.

17 Ovdje treba napomenuti da se, sukladno čl. 1106. ZOO/05, odredbe o doprinosu oštećenika vlastitoj šteti i sniženju naknade koje vrijede za imovinsku štetu na odgovarajući način primjenjuju i na neimovinsku štetu. 
krivnje što je, kako navodi Vizner, bilo moguće samo ako su obje stranke krive, ali kod nijedne ne postoji dolus. ${ }^{19}$ Sukladno tome, dolozno postupanje štetnika isključivalo je primjenu pravila o doprinosu oštećenika, zbog čega je u takvim slučajevima štetnik u cijelosti snosio štetu bez obzira na to je li oštećenik svojom nepažnjom doprinio njezinu nastanku. ${ }^{20}$

Ako pogledamo stavove austrijske pravne znanosti u tumačenju navedene odredbe, možemo primijetiti da se pojam krivnje oštećenika ne poistovjećuje s pojmom krivnje u smislu pretpostavke odgovornosti štetnika kada on odgovara po kriteriju subjektivne odgovornosti. Većina autora razlučuje pojam krivnje štetnika, koji se veže uz protupravno ponašanje kojim je nastala šteta i iz kojih pretpostavki proizlazi njegova odgovornost za štetu, od krivnje oštećenika. ${ }^{21}$ Oštećenikova "krivnja" se ne promatra na taj način, već ona ponajprije odražava subjektivni stav oštećenika prema njegovim vlastitim pravima i interesima, koji se ocjenjuje prema objektivnom kriteriju dužne pažnje s kojom prosječan čovjek postupa. Dužna pažnja uzima se kao pravni standard postupanja s kojim bi osoba trebala ulaziti u pravne odnose, kao mjerilo postupanja prosječnog čovjeka. ${ }^{22}$ Upravo je zbog toga adekvatna i za procjenu ponašanja oštećenika. S obzirom na to da je dužna pažnja ujedno kriterij prema kojem se stupnjuje krivnja ${ }^{23}$, valja imati na umu da se izostanak dužne pažnje oštećenika u zaštiti vlastitih prava ne očituje kao njegova krivnja, stoga je ne treba poistovjećivati s dužnom pažnjom koja je kriterij za utvrđivanje krivnje štetnika. Standard dužne pažnje ovdje ima ulogu pomoćnog mjerila kvalifikacije postupanja oštećenika, odnosno neprihvatljivosti njegova ponašanja usporedbom s ponašanjem prosječnog čovjeka, odnosno one osobe koja postupa s dužnom pažnjom. Iako u oba slučaja izostanak dužne pažnje predstavlja grubo zanemarivanje vlastitih ili tuđih prava, ponašanje koje je nerazumno, odnosno koje ne bi poduzeo prosječan čovjek, nemarnost oštećenika usmjerena je na vlastita pravna dobra i ona ne predstavlja skrivljeno protupravno ponašanje jer nebriga za vlastita pravna dobra (kada se

19 Vizner, B., Građansko pravo u teoriji i praksi, Tisak "Vjesnik", Zagreb, 1962., str. 553 -554 .

20 Vrhovni sud Narodne Republike Hrvatske, broj Gž-25/57.

21 Koziol, H., Die Schadensminderungspflicht, Juristische Blätter - JBL, vol. XX, 1972., str. 236 - 237. Vidi i Martin-Casals, M., Some Introductory and Comparative Remarks to the Decision of the Swiss Federal Court BGE/ATF 133 Ill 462 and to the 'Loss of Chance' Doctrine, European Review of Private Law, br. 6, 2008., str. 11043 - 1117, i Koch, B., Proportional Liability under Austrian Law, u: Gilead, I. et al. (ur.), Proportional Liability: Analytical and Comparative Perspectives, de Gruyter, Berlin, 2013.str. 77 - 98.

22 Klarić, op. cit. u bilj. 3, str. 211.

23 Klarić; Vedriš, op. cit. u bilj. 14, str. 597. 
time ne dira u prava drugih subjekata) nije protivna propisima. Prema tome, iako odredba paragrafa 1304. OGZ-a govori o krivnji oštećenika, ona se prema uvriježenom stavu austrijske pravne znanosti promatra kao nemarnost oštećenika prema vlastitim pravnim dobrima neovisno o tome je li takvo postupanje protupravno, za razliku od tradicionalnog poimanja krivnje štetnika. ${ }^{24}$

Prema stajalištu hrvatske sudske prakse, ali i pravne znanosti koje je bilo uvriježeno u vrijeme važenja paragrafa 1304. OGZ-a, krivnja oštećenika smatrala se nužnom pretpostavkom njegova doprinosa. Međutim, nedostatak navedenog tumačenja uočio se relativno brzo, osobito u onim slučajevima u kojima je nastanku štete doprinio neubrojivi ili maloljetni oštećenik koji nije deliktno sposoban i koji ne može skrivljeno postupati. Posljedica toga je bila nepravično otežana pozicija štetnika kojem se na teret stavljala cjelokupna šteta koju je bio u obvezi nadoknaditi bez obzira na činjenicu da se u određenom dijelu ona mogla pripisati jedino djelovanju oštećenika. ${ }^{25} \mathrm{U}$ skladu s takvim shvaćanjem proizlazio bi zaključak da na strani oštećenika ne može postojati doprinos ako oštećenik ne može biti kriv za radnju odnosno propust kojim je doprinio nastanku štete.

S obzirom na nepravičnost navedenog rješenja postavilo se pitanje treba li se onda u takvim slučajevima doprinos deliktno nesposobnog oštećenika ocjenjivati kroz doprinos osoba koje za njega odgovaraju jer su svojom krivnjom dopustile da se oštećenik nađe u situaciji u kojoj će pretrpjeti štetu. Ovakvo rješenje trpi nekoliko zamjerki. S jedne strane, ako zbog propusta u nadzoru odgovorne osobe oštećenik pretrpi štetu, onda takav propust ne može predstavljati doprinos oštećenika nastaloj šteti, već bi zbog toga oštećenik mogao od odgovorne osobe potraživati naknadu za štetu koju je pretrpio. U tom slučaju bila bi riječ o podjeli odgovornosti između dvaju štetnika prema oštećeniku. Prema tome, u takvoj situaciji propuštanje odgovorne osobe ne može se na taj način projicirati na oštećenika i smatrati njegovim propustom i doprinosom šteti.

$\mathrm{S}$ druge strane, ako je propust u nadzoru odgovorne osobe doveo do toga da oštećenik svojom radnjom ili propustom suuzrokuje štetu, može li se onda doprinos oštećenika ogledati u krivnji odgovorne osobe, kada već oštećenik ne može skrivljeno postupati? Ako prihvatimo da krivnja, u pravom smislu riječi definirana kao pretpostavka odgovornosti, nije pretpostavka doprinosa oštećenika, može se zaključiti da se doprinos oštećenika ne može ogledati ni u krivnji odgovorne osobe jer ako za doprinos oštećenika nije relevantna njegova

24 Koziol, H., Österreichisches Haftpflichtrecht I, Allgemeiner Teil, Manz, Wien, 1997., str. 234; Kaladić, I., Podijeljena odgovornost za štetu, Inženjerski biro, Zagreb, 2004. , str. 35.

25 Kaladić, I., Podijeljena odgovornost, u: Kuzmić, M. (ur.), Odgovornost za štetu, Inženjerski biro, Zagreb, 2004., str. 63 - 64. 
krivnja, ne možemo tražiti opravdanje doprinosa ni u krivnji odgovorne osobe. ${ }^{26}$ Prema tome, izostanak odgovarajućeg nadzora mogao bi jedino dovesti do toga da oštećenik ima pravo tražiti od osobe koja ga je bila dužna nadzirati onaj dio naknade za koji mu je umanjena odšteta zbog njegova doprinosa koji je uslijedio zbog neodgovarajućeg nadzora.

U nekim pravnim porecima u kojima je "krivnja" oštećenika pretpostavka doprinosa nastanku štete, ali u smislu nemarnosti prema zaštiti vlastitih pravnih dobara, ubrojivost se također nametnula kao pretpostavka doprinosa. ${ }^{27}$ $\mathrm{S}$ obzirom na to da bi u takvim slučajevima izostanak ubrojivosti na strani oštećenika, koji je očito doprinio nastanku vlastite štete, pa posljedično time i njegova doprinosa, suviše opteretio štetnika, navedenom problemu se doskočilo primijenivši odredbe o načelu pravičnosti, prema kojem naknada štete ipak tereti deliktno nesposobnog štetnika kada po procjeni suda okolnosti slučaja to zahtijevaju. Tako je, primjerice, u Švicarskoj zauzet stav da se načelo pravič-

${ }^{26}$ O suprotnim stajalištima ranije izraženima u praksi i pravnoj teoriji vidi Kaladić, I., O deliktnoj nesposobnosti oštećenika u svezi sobjektivnom odgovornošću štetnika, Pravo u gospodarstvu, vol. 37, 1998., str. 258 - 266.

27 Ovdje bismo mogli spomenuti contributory negligence, termin skovan u porecima common law sustava, koji označava obranu tuženika (štetnika) u predmetima naknade štete koji također dovodi do sniženja naknade koja pripada oštećeniku krivom jer nije upotrijebio dužnu pažnju (utvrđenu prema objektivnom standardu prosječno pažljivog čovjeka u danim okolnostima) u zaštiti vlastitih prava, što je posljedično dovelo do nastanka štete. Pretpostavke primjene contributory negligence su, osim uzročne veze između ponašanja oštećenika i nastanka štete, nepažnja oštećenika, odnosno njegova krivnja. Contributory negligence kao institut koji dovodi do umanjenja odgovornosti štetnika sličan je institutu doprinosa oštećenika prihvaćenog u kontinentalnim pravnim porecima. (U Velikoj Britaniji uređen je u Law Reform Act iz 1945. godine, više u: McMurray, E., I Expected Common Sense to Prevail: Vowles v. Evans, Amateur Rugby, and Referee Negligence in the U.K., Brooklyn Journal of International Law, vol. 29, br. 3, 2004., str. 1307 - 1344.) Međutim, u američkom sustavu primjena obrane contributory negligence dovodila je do potpunog isključenja odgovornosti štetnika, bez obzira na to o kojem stupnju nepažnje oštećenika se radilo. Zato je kasnije razvijena comparative negligence kao obrana štetnika koja, za razliku od contributory negligence, dovodi do podjele odgovornosti između štetnika i oštećenika te posljedično samo do sniženja naknade štete, ali ne i potpunog gubitka prava na odštetu. Više u: Robinette, C. J.; Sherland, P. G., Contributory or comparative: Which is the optimal negligence rule, Northern Illinois University Law Review, vol. 24, br. 1, 2003., str. 41 - 62. Iako se krivnja oštećenika ocjenjuje jednako kao krivnja štetnika, nije uvijek jasno hoće li smanjena sposobnost rasuđivanja biti od utjecaja na contributory negligence. Više o različitoj praksi američkih sudova vidi u: Flynn, J. P., Contributory negligence of incompetents, Washburn Law Journal, vol. 3, br. 2, 1964., str. $215-225$. 
nosti sadržano u odredbi čl. 54. Obligationenrecht može analogno primijeniti i na doprinos deliktno nesposobnog oštećenika. ${ }^{28}$ Slično rješenje prihvatila je i austrijska praksa primjenom odredbe paragrafa 1310. OGZ-a, kojim je propisana ovlast suda da neubrojivog štetnika ipak osudi na naknadu štete. ${ }^{29}$

U okvirima ranije hrvatske prakse bilo je prihvaćeno rješenje prema kojem se djelovanje oštećenika kojim se doprinosi nastanku štete počelo poistovjećivati s radnjom koju štetnik nije mogao spriječiti odnosno predvidjeti, kao razlogom za egzoneraciju štetnika u onim slučajevima u kojima se nije mogla utvrditi krivnja oštećenika niti krivnja osobe koja za njega odgovara. ${ }^{30}$

Međutim, takav egzoneracijski razlog bio bi prihvatljiv samo u onim slučajevima u kojima štetnik odgovara po načelu strože objektivne odgovornosti kao vlasnik opasne stvari, odnosno kao osoba koja se bavi opasnom djelatnošću u smislu odredaba čl. 1063. - 1067. ZOO/05. ${ }^{31}$ Iz razloga što je odredbom čl. 1067. st. 2. ZOO/05 izričito propisano da se vlasnik stvari oslobađa odgovornosti ako dokaže da je šteta nastala isključivo radnjom oštećenika ili treće osobe, koju on nije mogao predvidjeti i čije posljedice nije mogao ni izbjeći ni otkloniti.

Iz sadržaja navedene odredbe vidljivo je da se za oslobođenje od odgovornosti štetnika koji odgovara kao vlasnik opasne stvari ili nositelj opasne djelatnosti zbog doprinosa oštećenika traže dodatne pretpostavke, za razliku od pretpostavki utvrđivanja doprinosa u drugim slučajevima odgovornosti (obične objektivne ili subjektivne). Zbog pojačane odgovornosti štetnika kao vlasnika opasne stvari, on mora dokazati ne samo da je radnjom oštećenika prouzročena šteta, već da je radnja bila takve naravi da ju štetnik nije mogao predvidjeti i

28 Stark, E.; Oftinger, K., Schweizerisches Haftpflichtrecht, Zweiter Band, Allgemeiner Teil, Bd. 1, Schulthess Verlag, Zürich, 1995., str. 542; Das Schweizerische Obligationenrecht (OR), Das Schweizerische Zivilgesetzbuch (ZGB), od 30. ožujka 1911. s izmjenama do 2017. godine; https://www.admin.ch/opc/de/classified-compilation/19110009/index.html (15. rujna 2019.).

"Ako oštećenik ne uzmogne tim načinom zadobiti naknade; sudac rasudivši, da li oštetilac, sasvim tim što on nije običajno pri svojoj pameti, može biti okrivljen u tom posebnom slučaju; ili da li je oštećenik, htijući poštediti oštetioca zanemario obranu; ili najposlije imajući obzir na imovinu oštetioca i oštećenika, ima presuditi cijelu naknadu ili pristojan njezin dio."

Odluka Vrhovnog suda Narodne Republike Hrvatske Gž-357/59 od 5. ožujka 1959.

31 Ovdje treba upozoriti na razliku između egzoneracijskih razloga koji dovode do oslobođenja od odgovornosti štetnika kao što su, primjerice, viša sila, doprinos oštećenika, radnja treće osobe i sl., od ekskulpacijskih razloga kojima štetnik obara predmnjevu vlastite krivnje dokazujući svoju nekrivnju, odnosno da je postupao s dužnom pažnjom koja se od njega očekuje u pravnom prometu. Vidi Klarić; Vedriš, op. cit. u bilj. 14, str. 610 . 
da njezine posljedice nije mogao izbjeći ni otkloniti. Ispunjenje ove dodatne pretpostavke ne zahtijeva se u svim slučajevima u kojima štetnik odgovara po načelu objektivne odgovornosti, a osobito ne u slučaju subjektivne odgovornosti za štetu. Prema tome, razvidno je da takav stav i poimanje doprinosa oštećenika nije primjenjivo u svim slučajevima naknade štete.

Postupno se i u našoj sudskoj praksi relativizira pojam krivnje oštećenika iz paragrafa 1304. OGZ-a na način da je za utvrđivanje doprinosa relevantno ponašanje oštećenika koje mora predstavljati potpuni ili djelomični uzrok nastanka štete, dok je kvalifikacija navedenog ponašanja kao protupravna ili nemarna od utjecaja na način podjele štete između štetnika i oštećenika. ${ }^{32}$

\section{PODIJELJENA ODGOVORNOST}

Podijeljena odgovornost jest institut kojim se označava nešto sasvim drugo od doprinosa oštećenika. Ona ne podrazumijeva podjelu odgovornosti između oštećenika i štetnika, već podjelu odgovornosti između više osoba koje su sudjelovale u nastanku štete, u pravilu trećoj osobi. Budući da se pritom odgovornost dijeli između više osoba koje su svi štetnici, nužno je utvrditi postojanje pretpostavki odštetne odgovornosti za svakog pojedinog štetnika. Institut podijeljene odgovornosti sadržajno je uređen odredbama ZOO/05 u poglavlju pod nazivom Odgovornost više osoba za istu štetu u člancima 1107. - 1109 ., ali i u posebnom dijelu kojim je regulirana odgovornost za štete izazvane motornim vozilom u pogonu glede međusobnih odštetnih zahtjeva vlasnika motornih vozila (čl. 1072.).

Odredbom čl. 1072. ZOO/05 (prijašnjim čl. 178. ZOO/78) propisana je odgovornost vozača odnosno imatelja motornih vozila za štetu izazvanu motornim vozilom koju su međusobno pretrpjeli. Pritom je način podjele odgovornosti uređen po stupnju krivnje svakog štetnika, a u slučaju da krivnje nema, prema kriteriju pravičnosti. ${ }^{33} \mathrm{U}$ slučaju primjene navedene odredbe možemo govoriti

32 Odluka Vrhovnog suda Hrvatske broj Gž-48/62 od 16. siječnja 1962., za još primjera vidi Kaladić, op. cit. u bilj. 24, str. 261.

33 Treba napomenuti da postoje neke dvojbe oko tumačenja navedene odredbe, odnosno oko toga je li krivnja vozača samo kriterij podjele štete između dva štetnika koji odgovaraju po objektivnom načelu (kao što vozači motornih vozila inače odgovaraju prema trećima), ili je krivnja vozača pretpostavka njihove odgovornosti, pa je njihova odgovornost u tom slučaju subjektivna, a ne objektivna. Tako je u odluci VSH-a broj Gž-3088/68 od 29. listopada 1969. izneseno pravno shvaćanje prema kojem vlasnici motornih vozila odgovaraju po načelu krivnje glede međusobnih odštetnih zahtjeva. Isto i u odluci Županijskog suda u Zagrebu broj Gžn-15/10-2 od 30. studenog 2010. Čak i prilikom primjene st. 3. citiranog članka, koji se izrijekom 
o podijeljenoj odgovornosti za štetu uzrokovanu od strane dvaju štetnika glede njihovih međusobnih odštetnih zahtjeva, pa se samo u navedenim situacijama kada dolazi do primjene gore spomenutih normi može pravilno govoriti o institutu podijeljene odgovornosti. Takav zaključak nameće se jer upravo naziv podijeljena odgovornost odgovara stvarnom odnosu dvaju štetnika koji su prouzrokovali štetu te koji kao štetnici odgovaraju jedan drugome za njezin nastanak, što nije slučaj kada je oštećenik suuzrokovao štetu zajedno sa štetnikom, ali sebi samome, ne i drugim osobama.

U onim slučajevima kada je osoba pretrpjela štetu, ali je svojim djelovanjem doprinijela nastanku štete sebi, ali i drugome, onda je u odnosu na štetu počinjenu drugome možemo smatrati štetnikom. Samo u takvoj situaciji mogli bismo opravdano nazivati oštećenika istodobno i štetnikom. Dakle, doprinos oštećenika koji je pretrpio štetu ne možemo cijeniti kao dio njegove odgovornosti za nastanak štete, već samo kao okolnost koja utječe na odgovornost štetnika. Jedino u onim slučajevima kada se oštećenik može opravdano smatrati i štetnikom i u kojem se njegova odgovornost prosuđuje jednako kao odgovornost štetnika primjenjivat će se kriterij podijeljene odgovornosti, neovisno o tome što je štetnik/oštećenik pritom i sam pretrpio štetu.

\section{PRETPOSTAVKE DOPRINOSA OŠTEĆENIKA PREMA ODREDBI ČL. 1092. ZOO/05}

Ako bi se prihvatila teza da doprinos oštećenika dovodi do podjele odgovornosti između štetnika i oštećenika, onda bi kod ocjene njegova doprinosa bilo potrebno utvrđivati sve pretpostavke odgovornosti i na strani štetnika i na strani oštećenika, uključujući i njegovu krivnju ako to zahtijeva primjena pravila o subjektivnoj odgovornosti. ${ }^{34}$ Bez obzira na teškoće u tumačenju pretpostavki nužnih za nastanak doprinosa oštećenika koje postoje i danas u sudskoj prak-

primjenjuje u slučaju kad nema krivnje nijednog štetnika. S druge strane, Klarić i Vedriš smatraju da je odgovornost imatelja motornih vozila objektivna, a ne subjektivna, jer njihova krivnja nije pretpostavka odgovornosti već samo ključ razdiobe štete, odnosno kada krivnje nema, onda je to kriterij pravičnosti. Vidi Klarić; Vedriš, op. cit. u bilj. 14, str. 617. Drukčije pak shvaćanje iznosi Bikić, prema kojem subjektivna odgovornost postoji samo u st. 1. i 2., dok je u st. 3. propisana objektivna odgovornost imatelja vozila (Bikić, A., Naknada štete, Pravni fakultet Univerziteta u Sarajevu, Sarajevo, 2010., str. 74).

34 Slično i Crnić, I., Doprinos oštećenika vlastitoj šteti, Informator: instruktivno-informativni list za ekonomska i pravna pitanja, br. 5784-5785, 2009., str. 16 - 18. 
$\mathrm{si}^{35}$, ako se odmaknemo od stava da se podijeljena odgovornost poistovjećuje sa pojmom doprinosa oštećenika nastanku štete, onda je lako odbaciti i krivnju kao pretpostavku postojanja doprinosa. S obzirom na to da odredba čl. 1092. ZOO/05 ne govori o odgovornosti oštećenika za vlastitu štetu niti navodi oštećenikovu krivnju kao temelj njegova doprinosa, može se zaključiti da odgovornost ni krivnja oštećenika nisu pretpostavke doprinosa šteti.

Koje bi onda bile pretpostavke doprinosa oštećenika nastaloj šteti? Promotrimo li bolje odredbu čl. 1092. ZOO/05, možemo zaključiti da se doprinos oštećenika očituje u njegovu djelovanju (radnjom ili propustom) kada takvo djelovanje dovede do nastanka štete ili do njezina povećanja. Pritom je nevažno je li ono skrivljeno ili nije, zbog čega oštećenikov subjektivni odnos prema radnji ili propustu nije od utjecaja na ostvarenje doprinosa nastanku štete. Za postojanje doprinosa oštećenika dovoljna je činidba koja se može sastojati u aktivnom ili pasivnom držanju. Pritom ona mora biti adekvatna da bi mogla doprinijeti nastanku ili povećanju štete, odnosno ona mora biti adekvatna prouzročiti štetu jer bi izostanak takve radnje odnosno propusta doveo i do izostanka štete.

Uzročnu vezu oštećenikova djelovanja i nastale ili uvećane štete u pravilu neće biti teško dokazati primjenom teorija uzročnosti uvriježenih u odštetnom pravu. ${ }^{36}$ Međutim, u nekim slučajevima može se pojaviti dvojba o postojanju uzročne veze, osobito kada izostanak radnje oštećenika dovodi samo do izostanka vlastite štete, odnosno štete konkretnom oštećeniku, ali ne dovodi istodobno do izostanka štete u cijelosti, odnosno unatoč djelovanju oštećenika ostvario bi se štetni događaj.

Radi boljeg razumijevanja prikazat ćemo dva primjera iz sudske prakse. U prvom slučaju riječ je o alkoholiziranom vozaču koji je prouzrokovao prometnu nezgodu (štetni događaj), u kojoj je oštećenik zadobio tjelesne ozljede, odnosno pretrpio štetu. U konkretnom slučaju doprinos oštećenika mogao bi se očitovati u njegovoj radnji - ulasku u vozilo i vožnji s alkoholiziranim vozačem, odnosno propustu da primjeni dužnu pažnju i odbije vožnju. Neki sudovi smatraju da je oštećenik svojim ponašanjem doprinio da šteta njemu nastane ${ }^{37}$ iz razloga što do štete za konkretnog oštećenika ne bi došlo da nije ušao u vozilo, makar njegovo ponašanje ni na koji način nije uvjetovalo nastanak štetnog događaja, jer bi se

35 O aktualnim problemima sudske prakse u primjeni odredbe čl. 1092. ZOO/05 vidi više supra u poglavlju 2.

36 Opće prihvaćena teorija uzročnosti u hrvatskoj sudskoj praksi i pravnoj znanosti građanskog prava je adekvacijska teorija, odnosno teorija adekvatne uzročnosti. Vidi Klarić; Vedriš, op. cit. u bilj. 14, str. 595.

37 Presuda Vrhovnog suda Republike Hrvatske broj Rev-1054 /14-2 od 31. siječnja 2018. 
prometna nezgoda u svakom slučaju dogodila. S druge strane, neki misle ${ }^{38}$ da je takvim postupkom oštećenik pristao na rizik opasne vožnje - s alkoholiziranim vozačem - pa s obzirom da sam nije dovoljno brinuo o svojim pravima, ne može od štetnika potraživati naknadu štete zbog njihove povrede. ${ }^{39}$ Na prvu bi se moglo zaključiti da nema uzročne veze između radnje oštećenika i nastanka štetnog događaja, odnosno prometne nezgode, jer bi do nje došlo u svakom slučaju, bez obzira na postupanje oštećenika. Međutim, odredba čl. 1092. ZOO/05 govori o doprinosu oštećenika vlastitoj šteti, a ne štetnom događaju, tako da se u tom smislu može reći da postoji uzročna veza između radnje oštećenika - vožnje s alkoholiziranim vozačem, i nastanka štete - pretrpljenih ozljeda.

U drugom slučaju oštećeniku je nastala imovinska šteta na parkiranom vozilu padom prozorskog stakla sa zgrade. U ovom predmetu sud je zaključio da nema uzročne veze između radnje oštećenika koji se nepropisno parkirao ispred zgrade na nogostupu na kojem je bio postavljen znak zabrane zaustavljanja i parkiranja i nastale štete do koje je došlo zbog odvajanja stakla od prozorskog okvira uslijed lošeg održavanja i pada na vozilo oštećenika. ${ }^{40} \mathrm{U}$ ovom predmetu oštećenik svojom radnjom - parkiranjem ispred zgrade - svakako nije doprinio nastanku štetnog događaja koji se očituje u odvajanju stakla od prozorskog okvira i padanju - jer je do toga došlo isključivo zbog neodržavanja zgrade. Međutim, da se oštećenik nije parkirao na kritičnom mjestu, odnosno da je postupio u skladu s propisima i znakom zabrane parkiranja, njemu šteta ne bi nastala. Prema tome, u ovom predmetu ipak ne možemo negirati postojanje uzročne veze između radnje oštećenika i nastanka vlastite štete.

Ako prihvatimo kriterije prema kojima je sud utvrđivao postojanje uzročne veze u prvom slučaju, onda bi se primjenom jednakih kriterija došlo do zaključka o postojanju uzročne veze i u drugom slučaju. Usporedbom tih dvaju predmeta razvidno je da nije uvijek lako zaključiti postoji li uzročna veza između djelovanja oštećenika i nastale štete, pa će u konačnici takvo utvrđenje ovisiti o okolnostima konkretnog slučaja. Posebno se to očituje u slučaju propuštanja oštećenika da poduzme neku radnju koja je usmjerena na smanjenje nastanka štete, primjerice neprihvaćanje nekog medicinskog zahvata ili tretmana koji uobičajeno dovodi do poboljšanja zdravstvenog stanja pacijenta (oštećenika). ${ }^{41}$

38 Odluka Vrhovnog suda Republike Hrvatske broj Rev-361/08 od 21. svibnja 2008.

39 Crnić, op. cit. u bilj. 34, str. 16 - 18.

40 Odluka Županijskog suda u Bjelovaru broj Gž-3296/13-2 od 6. veljače 2015., više o tome u: Matijević, B., Doprinos oštećenika vlastitoj šteti - što se ne smatra doprinosom, Hrvatska pravna revija, vol. 17, br. 2, 2017., str. 1 - 10.

41 Takvo ponašanje oštećenika sudovi različito tumače. U odluci Vrhovnog suda Republike Hrvatske broj Gž-5/75 od 10. srpnja 1975. izneseno je pravno shvaćanje pre- 
Kada govorimo o pretpostavkama doprinosa oštećenika, nije dovoljno da je djelovanje oštećenika u uzročnoj vezi s nastankom štete, odnosno njezinim povećanjem. Zahtijeva se i određena neprimjerenost takvog postupanja ${ }^{42}$ Razlog tome je što se oštećeniku ne može predbaciti bilo koje ponašanje, makar je ono u uzročnoj vezi s nastalom štetom (primjerice, parkiranje auta ispred zgrade $s$ koje je pao prozor), ako je ono primjereno i uobičajeno ponašanje u skladu s objektivnim kriterijem dužne pažnje (parkiranje na obilježenom parkirnom mjestu ispred zgrade na kojoj nema vidljivih tragova oštećenja).

Kaladić napominje da ponašanje oštećenika osim što mora biti uzrokom štete mora biti i neprihvatljivo (neadekvatno) spram zaštite njegovih pravnih dobara i interesa, ali ne mora biti skrivljeno jer krivnja oštećenika nije pretpostavka njegova doprinosa. ${ }^{43} \mathrm{U}$ tom smislu se neprihvatljivost određenog ponašanja ocjenjuje prema okolnostima slučaja u skladu sa životnim iskustvom i standardima pravnog prometa ili, jednostavnije rečeno, prema ponašanju prosječnog čovjeka koji skrbi o svojim pravima i interesima. Slično i J. Crnić razlaže narav ponašanja oštećenika kojim se doprinosi nastanku štete, navodeći pritom da se njime mora odstupati od redovitog ponašanja drugih osoba $u$ istim okolnostima. ${ }^{44}$ Detaljnije to razrađuje I. Crnić ukazujući na to da oštećenika u njegovu ponašanju također tereti obveza postupanja sukladno načelu savjesnosti i poštenja, odnosno zabrane zloporabe prava propisane Zakonom o obveznim odnosima, u skladu s kojima se treba ponašati svaka osoba, pa i kad je riječ o postupanju prema vlastitim pravnim dobrima. ${ }^{45}$

Međutim, postavlja se pitanje kako odrediti koje ponašanje oštećenika će se smatrati neprimjerenim odnosno neprihvatljivim sa stajališta općeprihvaćenog društvenog ponašanja. Ako je riječ o ponašanju koje bi se inače smatralo protupravnim ponašanjem štetnika pri utvrđivanju pretpostavki odgovornosti za štetu, onda bi svakako takvo ponašanje bilo neprihvatljivo. Vrlo često je riječ upravo o takvom ponašanju oštećenika koje aktivira primjenu pravila o njegovu doprinosu, osobito u postupcima naknade štete proizašle iz prometa, primjerice, ako pješak prelazi cestu ili se kreće po kolniku na način protivan propisima o

ma kojem odbijanje kirurškog zahvata ne predstavlja doprinos oštećenika, dok je suprotan stav iznesen u odluci Vrhovnog suda Bosne i Hercegovine broj Gž-214/72 od 10. kolovoza 1972. Više o navedenoj problematici vidi u: Grbin, I., Neka pitanja naknade materijalne štete, Naša zakonitost, br. 10, 1986., str. 1315.

42 Crnić, op. cit. u bilj. 12, str. 1048, i Kaladić, op. cit. u bilj. 25, str. 78 - 79.

43 Kaladić, op. cit. u bilj. 24, str. 110.

44 Crnić, op. cit. u bilj. 12, str. 1048.

45 Crnić, I., Naknada štete, Odgovornost za štetu i popravljanje štete, Organizator, Zagreb, 1998., str. 91. 
sigurnosti prometa na cestama ili se vozač bicikla ne pridržava obveza propisanih navedenim pravilima. ${ }^{46}$ Ovdje valja napomenuti da se protupravno ponašanje oštećenika neće u svakom slučaju smatrati doprinosom nastanku štete jer ako protupravno ponašanje oštećenika nije u uzročnoj vezi s nastankom štete, takvo ponašanje, bez obzira na protupravnost, neće biti relevantno, odnosno neće automatski dovesti do primjene odredbe čl. 1092. ZOO/05.47,48

Teže je ponašanje oštećenika okarakterizirati kao neprihvatljivo ako ono nije protupravno, odnosno ako nema pravnih pravila koja mu nameću neku obvezu postupanja ili zabrane postupanja, kojim pravilima on izričito proturječi. Ipak neka ponašanja koja nisu protivna propisima, ali koja ne odgovaraju uobičajenom pažljivom postupanju prosječnog čovjeka, mogu uvelike doprinijeti nastanku ili povećanju štete. Shodno tome zauzet je stav da nema odgovornosti vozača koji je nanio teške tjelesne ozljede oštećenom koji je legao i zaspao ispod autodizalice zbog velikih vrućina, a kojeg vozač nije primijetio prilikom pokretanja vozila. ${ }^{49}$ U drugim slučajevima ocijenjeno je da se doprinos oštećenika očitovao u neopreznom kretanju po neosvijetljenom podrumskom stubištu, zatim u padu na skliskom terenu ${ }^{50}$ ili zaleđenoj cesti zbog nepažljivog kretanja ${ }^{51}$, kod skijaša koji je ostao stajati na opasnom dijelu skijaške staze na kojeg je naletio drugi skijaš, u nošenju neadekvatne obuće, cipela s visokim petama ${ }^{52} \mathrm{kada}$ je to dovelo do pada i ozljeđivanja i slično. ${ }^{53}$ Pravno dopuštenim, ali neprihvatljivim ponašanjem smatrat će se i lijeganje ispred zaustavljenog vozila ${ }^{54}$, odbijanje saniranja ozljeda pretrpljenih u štetnom događaju, davanje povoda nastanku štete - razdraživanje neubrojive osobe ${ }^{55}$, spavanje u polju koje je predviđeno za sjetvu i slično.

Posebno se o neprihvatljivom ponašanju (koje se ne smatra protupravnim) raspravljalo kad je do povećane štete došlo zbog toga što oštećeni nije poduzeo mjere radi sprečavanja povećanja štete, odnosno mjere kojima bi se ograničio

46 Čl. 112. - 113., 124. - 129. Zakona o sigurnosti prometa na cestama (Narodne novine, br. 67/2008, 48/2010, 74/2011, 80/2013, 158/2013, 92/2014, 64/2015 i 108/2017, dalje u tekstu: ZSPC).

47 Odluka Županijskog suda u Sisku broj Gž-594/2001-3 od 7. ožujka 2002.

48 Odluka VSRH-a broj 1129/06-2 od 15. ožujka 2017.

49 VSH Rev-1633/89, od 25. siječnja 1990. u: Bikić, op. cit. u bilj. 33, str. 50.

50 Odluka Općinskog suda u Puli-Pola broj P-107/12 od 30. srpnja 2012.

51 Odluka Općinskog suda u Sisku broj P-287/2011 od 21. listopada 2013.

52 Odluka Općinskog suda u Bjelovaru broj Pr-36/16-12 od 22. prosinca 2016.

53 Kaladić, op. cit. u bilj. 24, str. 145, 149 i 185.

54 VSRH broj Rev-956/1988 od 23. studenog 1998.

55 Kaladić, op. cit. u bilj. 25, str. 74. 
opseg štetnih posljedica radnje štetnika. S obzirom na to da se pravilo o doprinosu oštećenika odnosi na svaku radnju ili propuštanje kojim je šteta nastala ili se povećala, njime je obuhvaćeno i ono propuštanje oštećenika koje se sastoji u nepoduzimanju mjera saniranja nastale štete kako se njezine posljedice ne bi proširile. Pritom je dvojbeno do koje mjere oštećenika tereti obveza poduzimanja radnji radi sprečavanja povećanja štete, a da bi se njihovo nepoduzimanje moglo smatrati doprinosom povećanju štete. Osobito je to teško odrediti kada se od oštećenika koji je pretrpio kakve tjelesne ozljede traži podvrgavanje medicinskim tretmanima ili operativnom zahvatu, a imajući na umu pravo svake osobe na autonomiju i samoopredjeljenje glede skrbi o vlastitom tijelu i pravima. Radi razlučivanja navedene granice $\mathrm{u}$ jednom predmetu zauzeto je pravno shvaćanje da angažman oštećenika koji se od njega realno može očekivati i tražiti ne bi smio novčano, fizički ni psihički, imajući na umu sve okolnosti konkretnog slučaja, prelaziti razumnu mjeru (VSH Rev-282/86 od 19. studenog 1987.). ${ }^{56}$

Poštujući pravo svake osobe da slobodno odluči hoće li se i na koji način liječiti, neprihvaćanje medicinski prihvaćenih tretmana kojima se može uspješno sanirati šteta, a koji nisu pretjerano otegotni za oštećenika, smatrat će se neprihvatljivim ponašanjem koje ne može opravdati prebacivanje tereta odgovornosti na štetnika za one posljedice koje nisu primarno proizašle iz štetnog događaja, već su daljnje posljedice nastale štete, potencirane radnjama odnosno propustom oštećenika. Dakle, iako se oštećeniku ne može nametnuti obveza podvrgavanja operaciji ili nekom drugom tretmanu, posljedice nepoduzimanja mjera da se spriječe ili smanje daljnje posljedice štete ipak će se očitovati u smanjenju opsega odgovornosti štetnika i past će na teret oštećenog.

Ponašanje oštećenika kojim se ne vrijeđa nikakvo pravno pravilo, ali koje nije odgovarajuće u okolnostima situacije u kojima se poduzima, odnosno koje ne odgovara ponašanju prosječnog čovjeka koji vodi brigu o zaštiti vlastitih pravnih dobara i interesa, možemo odrediti kao pravno dopušteno, ali neprihvatljivo ponašanje kojim se doprinosi nastanku ili povećanju štete. Prema J. Crniću, takvo će ponašanje biti neprihvatljivo u svakom slučaju ako se njime odstupa od

56 Još primjera iz prakse vidi u: Kaladić, op. cit. u bilj. 24, str. 190: “Oštećenik je dužan podvrgnuti se operaciji radi smanjenja štete ako je zahvat bezopasan, ako oštećeniku neće izazvati veće bolove a može se očekivati poboljšanje oštećenikovog zdravstvenog stanja". BGE, 57., II., 67.: "Oštećeniku koji je obrađivao ugriznu ranu, iako je morao znati da se od ugriza psa može računati na infekciju, ukočenosti i grčeve, zbog čega se uvijek treba zatražiti liječnička pomoć, dosuđena je naknada u 2/3 dijela.; Od oštećenika se može očekivati da se podvrgne bezopasnoj operaciji, ako postoji izvjesnost da će ona bitno poboljšati njegovo tjelesno stanje”. BGE, 42. II., 245., 247. 
redovnog ponašanja drugih osoba u istim okolnostima. ${ }^{57}$ Prema Kaladiću takva neprimjerenost očituje se u propustu oštećenika da zaštiti svoja pravna dobra ili interese, što se mora utvrđivati u svakom konkretnom slučaju. ${ }^{58}$ Iz navedenog bi se moglo zaključiti da postoji objektivni kriterij prema kojem se prosuđuje ponašanje oštećenika - prema pažnji ili pozornosti u postupanju prosječnog čovjeka, odnosno prema njegovu odnosu prema zaštiti vlastitih pravnih dobara, odnosno prava i interesa. Subjektivni odnos ili doživljaj oštećenika prema njegovoj radnji neće biti relevantan za ocjenu postojanja doprinosa. Izostanak dužne pažnje da se zaštite vlastita prava ne mora rezultirati protupravnim ponašanjem, kao što je već ranije izneseno. Iz navedenog razloga nepažljivost u zaštiti vlastitih prava ne možemo okarakterizirati kao krivnju koja je inače pretpostavka subjektivne odštetne odgovornosti.

Ovdje treba napomenuti da neprihvatljivost ponašanja oštećenika u sebi sadržava kvalifikaciju određene nepažnje u postupanju. Iako je nepažnja oštećenika slična nepažnji kao stupnju krivnje štetnika jer se određuje prema objektivnom kriteriju, odnosno kako bi postupio prosječno pažljiv čovjek kada se brine o vlastitim stvarima, razlike između navedenih "nepažnji” ipak postoje.

Za početak valja reći da oštećenikovo nepažljivo ponašanje ne mora biti protupravno pa može, bez obzira na izostanak protupravnosti, dovesti do umanjenja obveze štetnika. Za razliku od oštećenikove nepažnje, pretpostavka štetnikove odgovornosti jest postupanje protivno propisima, protupravno ponašanje koje je rezultiralo nastankom štete..$^{59}$ Zatim, oštećenikova nepažnja utvrđivat će se i u slučajevima kada štetnik odgovara po načelu objektivne odgovornosti za štetu, odnosno kada krivnja štetnika nije pretpostavka njegove odgovornosti. Oštećenikovo ponašanje uvijek se prosuđuje prema objektivnom kriteriju, ali u skladu s okolnostima konkretnog slučaja, uspoređujući njegovo postupanje s postupanjem prosječno pažljivog čovjeka, makar se ponašanje štetnika neće uopće prosuđivati s aspekta krivnje u odnosu na počinjenu štetu.

Najznačajnija razlika postoji pri utvrđivanju deliktne sposobnosti osoba koje sudjeluju u nastanku štete. Osobe koje nisu deliktno sposobne ne odgovaraju za štetu koju su prouzročile već za njihove postupke u pravilu odgovaraju druge osobe u skladu s pretpostavkama propisanim zakonom. ${ }^{60}$ Međutim, ubrojivost ili deliktna sposobnost nije pretpostavka primjene odredbe čl. 1092. ZOO/05.

\footnotetext{
Crnić, op. cit. u bilj. 12, str. 1048.

58 Kaladić, op. cit. bilj. 25, str. 65.

59 I ovdje se upozorava na dvojbe pravne znanosti glede protupravnosti kao pretpostavke odgovornosti za štetu. Vidi bilješku broj 5 .
}

${ }^{60}$ Odgovornost za drugog - odredbe čl. 1055. - 1062. ZOO/05. 
Stoga se po važećim propisima pravilo o doprinosu oštećenika primjenjuje i na oštećenika koji nije ubrojiv, što znači da će doprinos maloljetnog djeteta koje nije deliktno sposobno ili neubrojive osobe dovesti do umanjenja odgovornosti štetnika. ${ }^{61}$ Pritom valja naglasiti da ako dijete svojim ponašanjem doprinese nastanku štete, stupanj pažnje koji se očekuje od djeteta u brizi za vlastita prava nije jednak onome odraslog ubrojivog čovjeka. Od djeteta se ne može očekivati da postupa s onom pažnjom s kojom bi postupala punoljetna zrela osoba. ${ }^{62} \mathrm{~S}$ druge strane, često se doprinos deliktno nesposobnih osoba pripisuje u izostanak dužne pažnje osoba koje su dužne voditi brigu o njima i za njih odgovaraju, ali u svakom slučaju bit će od utjecaja na opseg odgovornosti štetnika. ${ }^{63}$

S obzirom na izrečeno, kako bi se izbjeglo poistovjećivanje neprihvatljivog ponašanja oštećenika kojim se doprinosi nastanku štete sa skrivljenim ponašanjem štetnika, valjalo bi koristiti neki od termina već uvriježenih u pravnoj literaturi kada opisujemo ono oštećenikovo ponašanje koje ne odgovara ponašanju osobe koja se brine o zaštiti svojih prava na općeprihvaćen način.

Unatoč tome što subjektivni odnos oštećenika nije od utjecaja na postojanje doprinosa, ipak on može upućivati na neprihvatljivost ponašanja, osobito ako se u konkretnom slučaju utvrdi da je oštećenik postupao iz namjere, odnosno znajući i hotimice. ${ }^{64}$ Češće će subjektivni odnos oštećenika prema poduzetoj radnji biti samo od utjecaja na kvantificiranje njegova doprinosa, odnosno ocjenu visine doprinosa koja se oštećeniku može predbaciti. ${ }^{65}$ Neprihvatljivost ponašanja uvijek se ocjenjuje prema okolnostima konkretnog slučaja pa će u nekim situacijama određeno ponašanje biti neprihvatljivo sa stajališta životnog iskustva ili standarda ponašanja, dok se u drugim slučajevima takvo ponašanje neće smatrati neprimjerenim. Ponekad će to biti puno lakše utvrditi ako je ponašanje oštećenika nepropisno, protupravno, na primjer, u slučaju nepoštovanja prometnih propisa kada je takvo ponašanje pridonijelo nastanku štete ili njezinu uvećanju. U drugim slučajevima bit će teško razlučiti je li uopće neka radnja odnosno propust u uzročnoj vezi s nastankom štete, a ako jest, je li takvo ponašanje neprihvatljivo u toj mjeri da bi ga mogli smatrati doprinosom oštećenika.

${ }_{61} \quad$ Kaladić, I., Doprinos oštećenika sedmogodišnjeg djeteta vlastitoj šteti - komentar sudske odluke, Hrvatska pravna revija, vol. 6., br. X, 2006., str. 49.

${ }^{62}$ Primjerice, teško se može očekivati od sedmogodišnjeg djeteta da odbije vožnju s alkoholiziranim roditeljem.

63 Kaladić, op. cit. u bilj. 24, str. 262.

64 Namjera se određuje prema subjektivnim elementima - volji i znanju onoga koji postupa. Klarić; Vedriš, op. cit. u bilj. 14, str. 597.

65 Kaladić, op. cit. u bilj. 25, str. 65. 


\section{PRISTANAK OŠTEĆENIKA NA ŠTETU}

U ovom radu autor se primarno bavio usporedbom instituta doprinosa oštećenika vlastitoj šteti i podijeljene odgovornosti za štetu iz gore već rečenih razloga. Međutim, nužno je barem napomenuti da osim ovdje obrađenih instituta postoje još neki koji mogu biti od utjecaja na odgovornost štetnika, bilo da u potpunosti oslobađaju štetnika navedene odgovornosti, bilo da dovode do njezina umanjenja, odnosno sniženja naknade koju za pretrpljenu štetu potražuje oštećenik. ${ }^{66}$

Jedan od takvih instituta je i pristanak oštećenika na štetu (volenti non fit iniuria), propisan odredbom čl. 1054. ZOO/05 (čl. 163. ZOO/78). Prema navedenoj odredbi oštećenik koji na svoju štetu dopusti drugome poduzimanje neke radnje nema pravo od njega zahtijevati naknadu štete prouzročene tom radnjom. U stavku 2. propisano je ograničenje glede valjanosti pristanka oštećenika jer je ništetna ona izjava oštećenika kojom je pristao da mu se učini šteta radnjom koja je zakonom zabranjena.

Ako se vratimo na primjer oštećenika koji je pristao na vožnju s alkoholiziranim vozačem ${ }^{67}$, razvidno je da u pravnoj literaturi i praksi ${ }^{68}$ nije jedinstveno prihvaćeno je li navedenim postupkom oštećenik doprinio nastanku štete ili je takvim postupkom pristao na rizik opasne vožnje, odnosno na vožnju s alkoholiziranim vozačem, zbog čega ne može od štetnika potraživati naknadu.

U odluci VSRH-a u predmetu broj Rev-361/08 od 21. svibnja 2008. ${ }^{69}$ zauzeto je pravno shvaćanje da oštećenik koji svjesno pristaje na vožnju s alkoholiziranim vozačem pristaje i na štetu pritom nastalu u smislu odredbe čl. 163. st. 1 . ZOO/78. "Nitko nije ovlašten zahtijevati, na temelju zakona, da mu se popravi šteta koju je sam sebi prouzročio. U situaciji kad je utvrđeno da je oštećenik znao da je vozač automobila pod utjecajem alkohola, jer su prethodno zajedno pili u istom kafiću, te da vozač nema vozačku dozvolu i kad ga je u dogovoru s ostalim suvozačima nagovorio da ih odveze iz Cavtata, oštećenik je pristao

66 Do potpunog oslobođenja štetnika od odgovornosti za štetu doći će i u slučaju postupanja u nužnoj obrani ili stanju nužde (čl. 1052. st. 1. i 2. ZOO/05), dok će, primjerice, istodobno ostvarivanje koristi od štetne radnje za oštećenika dovesti do sniženja naknade (primjerice, u slučaju ostvarivanja primanja po osnovi zdravstvenog, mirovinskog i invalidskog osiguranja, vidi Kaladić, ibid., str. 80 - 81).

67 Vidi supra poglavlje 5. Pretpostavke doprinosa oštećenika prema odredbi čl. 1092. ZOO/05.

Crnić, I., Odštetno pravo, Zbirka sudskih rješidbi o odgovornosti za štetu i popravljanju štete s napomenama i propisima, Faber \& Zgombić Plus, Zagreb, 2004., str. 48.

Odluka Vrhovnog suda Republike Hrvatske broj Rev-361/08 od 21. svibnja 2008. 
na mogući nastanak vlastite štete. Riječ je o vlastitoj odgovornosti kod koje štetnik sam snosi posljedice štete prouzročene vlastitom štetnom radnjom ili propustom. Osoba koja sama sebi nanese štetu na vlastitim materijalnim ili nematerijalnim dobrima dužna je sama snositi štetne posljedice svoje radnje ili propuštanja. Zato nije u pravu revident kada smatra da je ovu situaciju trebalo ocjenjivati kroz primjenu čl. 192. ZOO-a.”

Iako je tužitelj smatrao da se u konkretnom slučaju nije mogla primijeniti navedena odredba, jer se iz navedenih činjeničnih utvrđenja ne bi moglo zaključiti da je on svojim ponašanjem dopustio štetniku da mu učini štetu, odnosno da je pristao na eventualne štetne posljedice koje mogu proizići iz vožnje u automobilu s vozačem bez vozačke dozvole i pod utjecajem alkohola, sudovi su zaključili suprotno.

U predmetu broj Rev-x 145/16-2 $2^{70}$ isti sud iznio je drukčije shvaćanje. Tužbenim zahtjevom tužitelj koji je zadobio tjelesne ozljede u prometnoj nezgodi kao suputnik u osobnom vozilu kojim je pod utjecajem alkohola upravljao vozač s kojim je tužitelj neposredno prije nastanka prometne nezgode konzumirao alkohol, potraživao je naknadu štete za pretrpljene ozljede. Sudovi su dijelom odbili tužbeni zahtjev kao neosnovan pozivom na odredbu čl. 177. st. 3. ZOO/78 budući da je tužitelj doprinio nastanku štete u omjeru od $50 \%$ jer je znao da je vozač u alkoholiziranom stanju i unatoč tomu pristao na vožnju. "Naime, kako je tužitelj (što nije sporno) prije nesreće zajedno s vozačem konzumirao alkoholna pića, pa je dakle znao da je vozač pod utjecajem alkohola i unatoč tomu pristao da se vozi u automobilu kojim je upravljao alkoholizirani vozač, nižestupanjski sudovi su obzirom na te činjenice, kao i utvrđeni stupanj alkoholiziranosti vozača pravilno zaključili da je tužitelju bilo, odnosno moralo biti poznato da je vozač pod utjecajem alkohola. Tužitelj je u vrijeme štetnog događaja imao 21 godinu, a to je dob u kojoj se može ocijeniti je li netko pod utjecajem alkohola i je li sposoban za vožnju, pa je tužitelj pristajući na vožnju u takvim okolnostima (vožnja u automobilu kojim upravlja osoba pod utjecajem alkohola ne može se smatrati vožnjom bez određenog rizika) pristao i na eventualne štetne posljedice takve vožnje. U okolnostima konkretnog slučaja pravilno su nižestupanjski sudovi ocijenili da je tužitelj svojim pristankom na vožnju s alkoholiziranim vozačem pridonio nastanku štete u omjeru od 50 \% (čl. 177. st. 3. ZOO-a), pa suprotna razlaganja tužitelja u tom pogledu nisu osnovana."

U istovrsnoj činjeničnoj situaciji VSRH je u predmetu Rev-1054/14-2 ${ }^{71}$ doprinos tužitelja cijenio primjenom odredbe čl. 1092. i čl. 1106. ZOO/05.

70 Odluka Vrhovnog suda Republike Hrvatske broj Rev-x 145/16-2 od 14. veljače 2017.

71 Presuda Vrhovnog suda Republike Hrvatske broj Rev-1054/14-2 od 31. siječnja 2018. 
Prije analize citiranih odluka valjalo bi utvrditi koje bi to bile sličnosti, a koje razlike između ovih dvaju instituta. Zajedničko im je to da oba utječu na odgovornost štetnika za štetu nastalu oštećeniku. Međutim, ne na jednak način niti u istom opsegu.

Doprinos oštećenika nastanku štete od utjecaja je na obujam i visinu štete za koju će odgovarati štetnik na način da će postojanje takvog doprinosa dovesti do razmjernog sniženja naknade ovisno u visini utvrđenog doprinosa. S druge strane, pristanak oštećenika na štetu dovodi do potpunog isključenja odgovornosti štetnika jer je navedenim pristankom, pod pretpostavkom njegove valjanosti, isključena protupravnost radnje kojom je učinjena šteta. ${ }^{72}$

Osim toga, pretpostavke doprinosa oštećenika su postojanje uzročne veze između ponašanja oštećenika i nastanka odnosno povećanja štete te neprimjerenost takvog ponašanja sa stajališta prosječnog čovjeka. Pristanak oštećenika jest izjava volje, pa su pretpostavke valjanosti takve izjave sposobnost ${ }^{73}$ oštećenika dati pravno relevantnu izjavu volje, svijest oštećenika o štetnim posljedicama na koje pristaje te volja da unatoč tome pristane na poduzimanje štetne radnje. ${ }^{74}$

Ako izostane neka od navedenih pretpostavki, "pristanak" oštećenika neće dovesti do isključenja protupravnosti štetne radnje, pa time ni do isključenja odgovornosti štetnika. Ista posljedica bit će i u slučaju davanja pristanka na poduzimanje zabranjene radnje, kako je propisano u stavku 2. čl. 1054. ZOO/05.

Međutim, takvo ponašanje oštećenika, makar ne udovoljava pretpostavkama za primjenu citiranog članka, nije irelevantno s aspekta štetnikove odgovornosti jer osoba koja pristaje da mu se učini šteta koja je zakonom zabranjena, odnosno koja pristaje na poduzimanje opasne radnje čijih štetnih posljedica nije svjesna, a trebala bi biti da je upotrijebila dužnu pažnju, ponaša se neprimjereno i neod-

72 Tako i Kaladić, op. cit. u bilj. 24, str. 117; Klarić, P., Odštetna odgovornost medicinskih ustanova i liječnika, u: Kuzmić, M. (ur.), Odgovornost za štetu, Inženjerski biro, Zagreb, 2004., str. 129.

73 Zahtijeva li primjena čl. 1054. ZOO/05 potpunu poslovnu sposobnost oštećenika, dvojbeno je pitanje. Naime, u većini suvremenih pravnih sustava za davanje pristanka na medicinski zahvat dovoljno je da je osoba koja daje pristanak sposobna za rasuđivanje, odnosno da je sposobna shvatiti značenje i posljedice davanja pristanka, a ne zahtijeva se njezina potpuna poslovna sposobnost, vidi Klarić, ibid., str. 129 - 130. Suprotno tome, naš Zakon o zaštiti prava pacijenata (Narodne novine, br. 169/2004, 37/2008) za navedeni pristanak zahtijeva punu poslovnu sposobnost pacijenta (čl. 17. st. 1.).

74 Oštećenik mora biti svjestan štetnih posljedica na koje pristaje kada dopušta poduzimanje radnje na svoju štetu. Ova pretpostavka najviše je došla do izražaja kod davanja informiranog pristanka pacijenta na medicinski zahvat koji mora biti dovoljno informiran o rizicima zahvata na koji pristaje; Klarić, ibid., str. 131. 
govarajuće $s$ aspekta zaštite i brige o vlastitim pravima. U tom slučaju mogli bismo govoriti o doprinosu oštećenika nastanku štete.

Ako se vratimo na gore prikazane slučajeve iz sudske prakse, možemo zaključiti da oštećenik koji pristaje na vožnju s alkoholiziranim vozačem pristaje na rizik opasne vožnje, ali ne pristaje na štetne posljedice koje iz takve vožnje mogu proizaći u smislu da je voljan pristati na povredu tjelesnog ili duševnog integriteta.

Prema tome, u takvoj činjeničnoj situaciji ponašanje oštećenika valjalo bi promatrati kao njegov doprinos nastanku štete jer se vlastitim neprimjerenim ponašanjem doveo u situaciju koja je rezultirala njegovom štetom.

\section{ZAHTJEV ZA NAKNADU ŠTETE POSREDNIH OŠTEĆENIKA}

Vrednovanje doprinosa oštećenika javlja se i u onim slučajevima u kojima posredni oštećenici, odnosno osobe na koje nije bila usmjerena štetna radnja, ali koji neovisno o tome posredno trpe štetu zbog stradanja neposrednog oštećenika, podnose zahtjev za naknadu štete. Pritom je potrebno utvrditi na koji način se na njih reflektira doprinos neposrednog oštećenika nastanku štete.

Šteta čijem je nastanku doprinio neposredni oštećenik bit će od utjecaja i na osnovanost zahtjeva za naknadu štete posrednih oštećenika. Naime, u onom dijelu u kojem neposredni oštećenik nije ovlašten zahtijevati naknadu štete jer ju je sam prouzročio nije opravdano ni da se u tom dijelu naknadi šteta posrednim oštećenicima. Prema tome, svako umanjenje odgovornosti štetnika iz razloga doprinosa neposrednog oštećenika šteti dovodi do umanjenja odgovornosti štetnika u odnosu na posredne oštećenike. Posredni oštećenik svoje pravo na naknadu štete izvlači iz štete koja se dogodila neposredno oštećenom na način da se njegov zahtjev temelji na drukčijim pretpostavkama negoli zahtjev neposredno oštećenog. Za posrednog oštećenika štetni događaj jest šteta koja se dogodila neposrednom oštećeniku zbog kojih posljedica sada štetu trpi i posredni, bilo u vidu povrede prava osobnosti zbog smrti/invaliditeta oštećenog, bilo u vidu imovinske štete zbog gubitka uzdržavanja, troškova pogreba i slično.

Neovisno o tome što se osnovanost zahtjeva posrednog oštećenika temelji na drugim pretpostavkama, doprinos neposrednog oštećenika šteti će se reflektirati i na njegovo pravo jer štetnikova odgovornost prema posrednom oštećeniku ne može prelaziti granice njegove odgovornosti prema neposrednom. Osim toga, do daljnjeg umanjenja odgovornosti štetnika prema posredno oštećenom može dovesti i radnja posredno oštećenog kojom je on doprinio nastanku vlastite štete koju trpi kao posljedicu štete koju je pretrpio neposredno oštećenik. Drugim 
riječima, u nekim slučajevima će pravo posrednog oštećenika na naknadu štete biti dvostruko umanjeno, jednom zbog doprinosa neposrednog oštećenika nastanku štete iz koje proizlazi i njegova šteta, a drugi put jer je sam posredno oštećeni doprinio nastanku vlastite štete.

Sukladno ustaljenoj sudskoj praksi, doprinos posrednog oštećenika vlastitoj šteti očituje se u njegovu propustu da provodi odgovarajući nadzor nad neposrednim oštećenikom o kojem je dužan skrbiti, a zbog čega je ovaj - neposredno oštećeni - doprinio nastanku štetnog događaja. ${ }^{75,76}$ Primjerice, maloljetni oštećenik koji se bez nadzora roditelja igrao i pritom popeo na trafostanicu i nastradao. ${ }^{77}$ Slijedom čega bi se u navedenom slučaju prilikom utvrđivanja odgovornosti štetnika njegova odgovornost trebala umanjiti cijeneći doprinos neposredno oštećenog nastanku štete te ako bi zahtjev za naknadu štete postavili i njegovi roditelji kao posredni oštećenici zbog štete koju trpe kao posljedicu stradavanja njihova djeteta, onda bi se njihov zahtjev trebao cijeniti imajući u vidu i doprinos djeteta nastanku štete i njihov doprinos zbog propusta u nadzoru.

\section{ZAKLJUČAK}

Odgovornost za štetu vrlo često nastaje kao posljedica ostvarenja nekih neželjenih društvenih situacija. S obzirom na njihovu učestalost, naknada štete predmetom je mnogih sudskih postupaka. Hoće li pojedini zahtjev za naknadu štete biti osnovan, ovisit će ponajprije o tome jesu li ispunjene sve pretpostavke odgovornosti za štetu u svakom konkretnom slučaju. Međutim, na osnovanost

75 "Iz obrazloženja nižestupanjskih odluka proizlazi da su odlučujući o visini pravične novčane naknade zbog pretrpljenih duševnih bolova zbog smrti bliske osobe na temelju odredbe čl. 200. st. 1 . ZOO te o visini materijalne štete u smislu odredbe čl. 193. ZOO, sudovi ocijenili doprinos oštećenika nastanku štete u omjeru od 15 \% u smislu odredbe čl. 192. st. 1. ZOO u vezi s odredbom čl. 160. st. 3. ZOO zbog propusta nadzora nad maloljetnom osobom, te su dosuđene iznose nematerijalne i materijalne štete umanjili razmjerno utvrđenom omjeru suodgovornosti, čime su prema ocjeni ovog suda pravilno primijenili materijalno pravo." Rev-x 1209/16-2 od 18. siječnja 2017.

76 "Obzirom na utvrđenje sudova o postojanju suodgovornosti 1. i 2.tužitelja kao roditelja mldb. Irfana nastanku štetnog događaja, a zbog njihovog propusta da nadziru malodobno dijete u igri (čl. 94. st. 2. OZ) a što je ocijenjeno njihovim doprinosom u smislu odredbe čl. 1067. st. 3. ZOO, pravilno su sudovi polazeći od suodgovornosti stranaka u omjeru 50\% : 50\% u tom omjeru tužiteljima dosudili pripadajuću naknadu štete, sve na temelju odredbe čl. 1092. u svezi s odredbom čl. 19. i 1093. ZOO." Rev 1477/09-3 od 20. travnja 2011.

77 Kaladić, op. cit. u bilj. 61, str. 59 - 62. 
zahtjeva oštećene osobe utjecat će i one okolnosti koje mogu biti razlogom umanjenja ili čak isključenja odgovornosti štetnika. U tom smislu možemo govoriti o nekoliko relevantnih instituta - doprinosu oštećenika vlastitoj šteti, podijeljenoj odgovornosti, pristanku oštećenika na štetu itd.

U ovom radu naglasak je bio na uočavanju razlika između dvaju instituta koji se najčešće pogrešno poistovjećuju po svom učinku i sadržaju. Riječ je o doprinosu oštećenika vlastitoj šteti i podijeljenoj odgovornosti za nastalu štetu. Razlog u teškoćama razlikovanja treba potražiti u povijesnoj genezi instituta doprinosa oštećenika, koji je bio uređen odredbama OGZ-a, ZOO/78 i ZOO/05. U vrijeme važenja OGZ-a paragraf 1304. govorio je o krivnji oštećenika za nastanak štete, dok su odredbe ZOO/78, makar sadržajno jednake odredbama ZOO/05, govorile o podijeljenoj odgovornosti oštećenika za nastalu štetu.

Inzistiranje na odgovarajućoj upotrebi ovih instituta važno je zbog toga što se za postojanje doprinosa oštećenika nastanku štete zahtijevaju drukčije pretpostavke od onih koje su nužne za postojanje podijeljene odgovornosti. Prilikom utvrđivanja doprinosa oštećenika ne ocjenjuje se njegov subjektivni odnos spram radnje odnosno propusta kojim se doprinosi nastanku ili povećanju štete. Njegovo ponašanje promatra se kroz objektivne kriterije neprihvatljivosti takvog ponašanja s aspekta prosječnog čovjeka, odnosno načina na koji bi on postupio u sličnoj situaciji. Za razliku od toga, podijeljena odgovornost već po svom nazivu upućuje na podjelu odgovornosti između dviju ili više osoba za nastalu štetu. Prema tome, da bismo mogli govoriti o podijeljenoj odgovornosti, potrebno je ispunjenje svih pretpostavki odgovornosti za štetu, protupravnost ponašanja, pa i skrivljeno ponašanje svih štetnika, ako se primjenjuju pravila o subjektivnoj odgovornosti. Slijedom navedenog, ako odnos između štetnika i oštećenika promatramo na taj način, onda bi se i na strani oštećenika morale utvrđivati sve one okolnosti relevantne za postojanje odgovornosti za vlastitu štetu.

Navedeno tumačenje ne bi bilo prihvatljivo jer oštećenik ne odgovara za štetu koju je sam sebi prouzročio, pa se na njega ne mogu primjenjivati isti kriteriji koji se primjenjuju na štetnika. Od njega se ne traži da bude brižan prema vlastitim pravima i interesima na način koji bi za posljedicu nepostupanja imao primjenu pravila o odgovornosti za štetu prema samome sebi. U tom smislu nebriga za sebe ne dovodi do vlastite odgovornosti za štetu, već ona može biti od utjecaja na opseg i visinu odgovornosti štetnika. U tome se i očituje svrha doprinosa oštećenika, a to je da se zbog manjka interesa za zaštitu vlastitih prava odgovornost za nastalu štetu ne pripisuje u cijelosti štetniku.

Podijeljena odgovornost postojat će u onim slučajevima u kojima su dvije osobe ili više njih uzrokovale štetu trećim osobama ili sebi međusobno, makar 
su pritom i same pretrpjele štetu. Jedino bismo u tom slučaju mogli govoriti o sjedinjenju osobe štetnika i oštećenika u jednoj osobi. Tada bi ista osoba za dio štete koji je uzrokovala drugome odgovarala kao štetnik zajedno s osobama koje su štetu suuzrokovale, dok bi za dio štete koji je sama pretrpjela mogla potraživati naknadu od štetnika koji ju je uzrokovao, prilikom čega bi se moglo utvrđivati je li u tom smislu i ta osoba sama doprinijela nastanku vlastite štete. Pretpostavke doprinosa oštećenika su objektivno postavljene - s jedne strane zahtijeva se neprihvatljivost ponašanja (radnjom ili propustom) oštećenika, a s druge strane da je takvo neprihvatljivo ponašanje u uzročnoj vezi s nastankom ili povećanjem štete. Zadatak sudova je pritom ocijeniti što se smatra neprihvatljivim ponašanjem u konkretnom slučaju sukladno objektivnim kriterijima te je li takvo ponašanje uzrokom nastanka štete. Pritom valja istaknuti da neprihvatljivo ponašanje ne mora nužno biti ono koje je protivno propisima, iako će to najčešće biti tako. Ono će se smatrati neprihvatljivim već ako se njime odstupa od društveno uvriježenog načina ponašanja u konkretnim okolnostima. Pritom valja napomenuti da društveno prihvatljivo ponašanje kao kriterij za određenje neprihvatljivog ponašanja neće biti jednako za sve oštećenike. Ponekad se određeni stupanj pažnje s kojim postupa deliktno sposobna prosječna osoba kada se brine o vlastitim pravima neće moći očekivati od djeteta ili osobe smanjene ubrojivosti.

Dvojbe oko toga koji institut treba primijeniti u pojedinim slučajevima postoje i pri primjeni instituta doprinosa oštećenika i pristanka oštećenika na štetu jer nije uvijek lako odrediti kojim ponašanjem oštećenik doprinosi nastanku štete, a kojim pristaje na štetu. Budući da navedeni instituti različito utječu na odgovornost štetnika, valja pomno ocijeniti koje pretpostavke su u konkretnom slučaju ispunjene, a o kojima ovisi njihova primjena.

Konačno, u radu je skrenuta pozornost na mogućnost "dvostrukog vrednovanja" doprinosa oštećenika nastaloj šteti - jednom kroz doprinos neposredno oštećenog, onog prema kojem je izravno usmjerena štetna radnja, a drugi put kroz doprinos posredno oštećenog, odnosno onog koji štetu trpi kao posljedicu štete nastale neposrednom oštećeniku. Reflektiranje doprinosa neposrednog oštećenika na osnovanost zahtjeva za naknadu štete posrednog oštećenika počiva na premisi prema kojoj odgovornost štetnika prema posredno oštećenom ne može biti veća nego li je njegova odgovornost prema neposrednom oštećeniku. Upravo iz razloga što se njegova šteta zasniva na šteti neposredno oštećene osobe. Ako je pritom i posredno oštećeni doprinio nastanku ili povećanju štete, zbog vlastitog propusta da ispuni obveze koje ima prema neposrednom oštećeniku (primjerice, zbog nedostataka u nadzoru ili skrbi maloljetnog oštećenika) ili na neki drugi način, onda će već umanjena odgovornost štetnika biti dodatno umanjena. 
Usporedbom zakonskih odredbi koje uređuju institut doprinosa oštećenika vlastitoj šteti i institut podijeljene odgovornosti nastojalo se upozoriti na svrhu navedenih instituta radi lakšeg uočavanja razlika koje između njih postoje. Terminološka nekonzistentnost u njihovoj uporabi ogleda se u mnogim aktualnim odlukama sudske prakse. Međutim, treba imati na umu da problem nije samo terminološke naravi jer neadekvatno korištenje navedenih instituta ima za posljedicu i drukčije pretpostavke nužne za njihovu primjenu.

\section{LITERATURA}

\section{Knjige i članci:}

1. Bikić, A., Naknada štete, Pravni fakultet Univerziteta u Sarajevu, Sarajevo, 2010.

2. Crnić, I., Doprinos oštećenika vlastitoj šteti, Informator : instruktivno-informativni list za ekonomska i pravna pitanja, br. 57, 2009., str. 16 - 18.

3. Crnić, I., Naknada štete, Odgovornost za štetu i popravljanje štete, Organizator, Zagreb, 1998.

4. Crnić, I., Odštetno pravo, Zbirka sudskih rješidbi o odgovornosti za štetu i popravljanju štete s napomenama i propisima, Faber \& Zgombić Plus, Zagreb, 2004.

5. Crnić, J., Odgovornost više osoba za istu štetu i podijeljena odgovornost, Naša zakonitost, br. 9-70, 1987., str. 1040 - 1053.

6. Flynn, J. P., Contributory negligence of incompetents, Washburn Law Journal, vol. 3, br. 2, 1964., str. $215-225$..

7. Grbin, I., Popravljanje imovinske štete, 1. dio, Informator, br. 5441-5442, 2006. , str. $5-7$.

8. Grbin, I., Popravljanje imovinske štete, 2. dio, Informator, br. 5443, 2006, str. $5-7$.

9. Kaladić I., Doprinos oštećenika - deliktno nesposobne osobe u vlastitoj šteti nepropisnim prevoženjem u osobnom automobilu, Hrvatska pravna revija, vol. 6, br. 5, 2006., str. 47 - 49.

10. Kaladić, I., Doprinos oštećenika - sedmogodišnjeg djeteta vlastitoj šteti - komentar sudske odluke, Hrvatska pravna revija, vol. 6, br. X, 2006., str. $59-62$.

11. Kaladić, I., O deliktnoj nesposobnosti oštećenika u svezi s objektivnom odgovornošću štetnika, Pravo u gospodarstvu, vol. 37, 1998., str. 258 - 266.

12. Kaladić, I., Podijeljena odgovornost, u: Kuzmić, M. (ur.), Odgovornost za štetu, Inženjerski biro, Zagreb, 2004., str. 57 - 83. 
13. Kaladić, I., Podijeljena odgovornost za štetu, Inženjerski biro, Zagreb, 2004.

14. Klarić, P., Odštetna odgovornost medicinskih ustanova i liječnika, u: Kuzmić, M. (ur.), Odgovornost za štetu, Inženjerski biro, Zagreb, 2004., str. 106-148.

15. Klarić, P., Odštetno pravo, Narodne novine, Zagreb, 1995.

16. Klarić, P.; Vedriš, M., Građansko pravo, Narodne novine, Zagreb, 2008.

17. Koch, B., Proportional Liability under Austrian Law, u: Gilead, I. et al. (ur.), Proportional Liability: Analytical and Comparative Perspectives, de Gruyter, Berlin, 2013., str. 77 - 98.

18. Koziol, H., Die Schadensminderungspflicht, Juristische Blätter - JBL, vol. XX, 1972., str. 236 - 237.

19. Koziol, H., Österreichisches Haftpflichtrecht I, Allgemeiner Teil, Manz, Wien, 1997.

20. Martin-Casals, M., Some Introductory and Comparative Remarks to the Decision of the Swiss Federal Court BGE/ATF 133 Ill 462 and to the 'Loss of Chance' Doctrine, European Review of Private Law, br. 6, 2008., str. 1043 - 1117.

21. Matijević, B., Doprinos oštećenika vlastitoj šteti - što se ne smatra doprinosom, Hrvatska pravna revija, vol. 17, br. 2, 2017., str. 1 - 10.

22. McMurray, E., I Expected Common Sense to Prevail: Vowles v. Evans, Amateur Rugby, and Referee Negligence in the U.K., Brooklyn Journal of International Law, vol. 29, br. 3, 2004., str. 1307 - 1344.

23. Robinette, C. J.; Sherland, P. G., Contributory or comparative: Which is the optimal negligence rule, Northern Illinois University Law Review, vol. 24, br. I, 2003., str. $41-62$.

24. Stark, E.; Oftinger, K., Schweizerisches Haftpflichtrecht, Zweiter Band, Allgemeiner Teil, Bd. 1, Schulthess Verlag, Zürich, 1995.

25. Stipković, Z., Protupravnost kao pretpostavka odgovornosti za štetu, Pravni fakultet, Zavod za građanskopravne znanosti i porodično pravo, Zagreb, 1991.

26. Vizner, B., Građansko pravo u teoriji i praksi, Tisak "Vjesnik", Zagreb, 1962.

27. Vuković, M., Obvezno pravo, knjiga I., Uvod, odgovornost za štetu i ostale vanugovorne obveze, Školska knjiga, Zagreb, 1956.

\section{Pravni akti:}

1. Das Schweizerische Obligationenrecht (OR), Das Schweizerische Zivilgesetzbuch (ZGB), od 30. ožujka 1911. s izmjenama do 2017. godine; https:// www.admin.ch/opc/de/classified-compilation/19110009/index.html (15. rujna 2019 .) 
2. Opći građanski zakonik, Justizgesetzsammlung $1 / 1811$.

3. Pomorski zakonik (Narodne novine, br. 181/2004, 76/2007, 146/2008, 61/2011, 56/2013, 26/2015 i 17/2019).

4. Zakon o obveznim odnosima (Službeni list SFRJ 29/1978, 39/1985, 46/1985, 57/1989; Narodne novine, br. 3/1991, 73/1991, 111/1993, 3/1994, 107/1995, 7/1996, 112/1999 i 88/2001).

5. Zakon o obveznim odnosima (Narodne novine, br. 35/2005, 41/2008, $78 / 2015$ i 29/2018).

6. Zakon o obveznim osiguranjima u prometu (Narodne novine, br. 151/2005, 36/2009, 75/2009, 76/2013 i 152/2014).

7. Zakon o radu (Narodne novine, broj 93/2014 i 127/2017).

8. Zakon o zaštiti na radu (Narodne novine, br. 71/2014, 118/2014, 154/2014, 94/2018 i 96/2018).

9. Zakon o odgovornosti za štetu nastalu uslijed terorističkih akata i javnih demonstracija (Narodne novine, br. 117/2003).

10. Zakon o odgovornosti Republike Hrvatske za štetu uzrokovanu od pripadnika hrvatskih oružanih i redarstvenih snaga tijekom Domovinskog rata (Narodne novine, br. 117/2003).

11. Zakon o medijima (Narodne novine, br. 59/2004, 84/2011 i 81/2013).

12. Zakona o sigurnosti prometa na cestama (Narodne novine, br. 67/2008, 48/2010, 74/2011, 80/2013, 158/2013, 92/2014, 64/2015 i 108/2017)

13. Zakon o trgovačkim društvima (Narodne novine, br. 111/1993, 34/1999, 121/1999, 52/2000, 118/2003, 107/2007, 146/2008, 137/2009, 111/2012, 125/2011, 68/2013 i 110/2015).

14. Zakon o sudovima (Narodne novine, br. 28/2013, 33/2015, 82/2015, 82/2016 i $67 / 2018)$.

\section{Sudska praksa:}

1. Općinski sud u Bjelovaru broj Pr-36/16-12 od 22. prosinca 2016.

2. Općinski sud u Puli-Pola broj P-107/12 od 30. srpnja 2012.

3. Općinski sud u Sisku broj P-287/2011 od 21. listopada 2013.

4. Vrhovni sud Bosne i Hercegovine broj Gž-214/72 od 10. kolovoza 1972.

5. Vrhovni sud Hrvatske broj Gž-48/62 od 16. siječnja 1962.

6. Vrhovni sud Hrvatske broj Gž-5/75 od 10. srpnja 1975.

7. Vrhovni sud Hrvatske broj Rev-282/86 od 19. studenog 1987. 
8. Vrhovni sud Hrvatske broj Rev-1633/89, od 25. siječnja 1990.

9. Vrhovni sud Narodne Republike Hrvatske Gž-357/59 od 5. ožujka 1959.

10. Vrhovni sud Republike Hrvatske broj 1129/06-2 od 15. ožujka 2017.

11. Vrhovni sud Republike Hrvatske broj Rev 1477/09-3 od 20. travnja 2011.

12. Vrhovni sud Republike Hrvatske broj Rev-361/08 od 21. svibnja 2008.

13. Vrhovni sud Republike Hrvatske broj Rev -1555/09-3 od 5. studenog 2014.

14. Vrhovni sud Republike Hrvatske broj Rev-903/10-2 od 3. studenog 2010.

15. Vrhovni sud Republike Hrvatske broj Rev-956/1988 od 23. studenog 1998.

16. Vrhovni sud Republike Hrvatske broj Revr -174/14-2 od 28. svibnja 2014.

17. Vrhovni sud Republike Hrvatske broj Rev-x 1209/16-2 od 18. siječnja 2017.

18. Županijski sud u Bjelovaru broj Gž-3296/13-2 od 6. veljače 2015.

19. Županijski sud u Sisku broj Gž-594/2001-3 od 7. ožujka 2002.

20. Županijski sud u Zagrebu broj Gž-7104/15-4 od 9. siječnja 2019.

21. Županijski sud u Zagrebu broj Gž-7410/15-6 od 28. studenog 2017.

22. Županijski sud u Zagrebu broj Gžn-2371/14-2 od 8. travnja 2015.

23. Županijski sud u Zagrebu broj Gžn-2516/14-2 od 7. veljače 2017.

24. Županijski sud u Zagrebu broj Gžn-430/13-2 od 28. siječnja 2014. 
Summary

\section{Dijana Vragović*}

\section{DIFFERENTIATING BETWEEN THE LEGAL PRINCIPLES OF CONTRIBUTION OF THE INJURED PARTY TO HIS OWN INJURY AND APPORTIONED LIABILITY}

There is a need to distinguish, both in legal theory and practice, two different legal principles - contribution of the injured party to his own injury and apportioned liability, formerly defined in Article 192 of the Civil Obligations Act (1978) and currently in Article 1092 of the Civil Obligations Act (2005). It is important to use the precise terminology when applying the legal principles, not only for the sake of using accurate nomenclature per se, but also in order to ensure that the correct requirements are identified. In this article, the author provides a review of recent Croatian case law, as well as of the academic discussion of this topic. Finally, the author makes a conclusion about the correct terminology and requirements for applying the legal principle of contribution of the injured party to his own injury when discussing liability for damage and compensation reduction.

Keywords: contribution of the injured party, apportioned liability, volenti non fit iniuria, compensation of damage, indirect victims

* Dijana Vragović, mag. iur., Senior Judicial Advisor at the County Court in Zagreb temporarily assigned to the Supreme Court of the Republic of Croatia, Trpimirova 25, Zagreb; dijanahrstic@yahoo.com;

ORCID ID: orcid.org/0000-0002-3025-0698 